\title{
The Investigation of the Attitudes of Teachers towards Using Student Centered Teaching Methods and Techniques
}

\author{
Elif Akdemir ${ }^{1, *}$, Ceyda Özçelik² \\ ${ }^{1}$ Ereğli Education Faculty, Zonguldak Bülent Ecevit University, Turkey \\ ${ }^{2}$ Turkish Ministry of National Education, Turkey
}

Copyright $\odot 2019$ by authors, all rights reserved. Authors agree that this article remains permanently open access under the terms of the Creative Commons Attribution License 4.0 International License

\begin{abstract}
The importance given to student-centered teaching methods and techniques is increasing as a reflection of the constructivist approach. This study was conducted with the aim of determining the attitude of teachers working in secondary schools to use student centered teaching methods and techniques and compare it based on the gender, subject, seniority year, and school type variables. The survey method was used in the study. The population of the research is 409 subject teachers who work in the central schools of one city located in the Blacksea Region of the Turkey in the 2017-2018 academic year. 10 middle school were selected using random sampling. 135 teachers participating in the research voluntarily. The data related to the study were obtained by attitude scale for using student centered teaching methods and techniques. Findings indicated that teachers' attitudes towards using student- centered teaching methods and techniques do not change according to gender, school type and seniority year variables. However, according to the subject variable, there was a significant difference in the given importance sub-dimension when there was no meaningful difference in resistance, cost-benefit, positive effects sub-dimensions and scale-wide differences. Further studies should investigate why teachers' attitudes towards using student centered teaching methods and techniques are high in skills lessons than verbal and numerical lessons.
\end{abstract}

Keywords Student-Centered Teaching, Teaching Methods, Attitude

\section{Introduction}

Along with today's developing technology, the characteristics required in individuals are changing. One of the factors that will provide this change is education.
Therefore, different approaches and innovations towards education are at the forefront. Nowadays it is important to educate individuals who produce, interpret and question information rather than individuals who consume information [20]. Psychological and pedagogical functions provide the link between the methods employed and assumptions of how individual learn [9]. Instead of a teaching-centered approach to education, the learning-centered approach to education will play an active role at this stage in order to provide the desired traits of the individual. Student centered learning environments enables students to address their learning needs.

Student centered learning is grounded in a constructivist view of learning. Constructivist theory, the result of research by scientists such as J. Dewey, L. Vygotsky, J. Piaget, and D. Ausubel J. Bruner, is the theory that forms the basis of student-centered teaching. [19] emphasized the importance of student-centered work in situations such as constructing knowledge, learning to learn, and making sense in the mind. Student centered learning is a learning in which students influence the content, activities, materials, and pace of learning [7]. Student-centered education has been defined as structuring the educational process in such a way as to provide individual participation at every stage, taking into consideration individual characteristics, having scientific thinking and communication skills, learning to learn, productive, accessing and using knowledge, adopting universal values, using technology effectively [16]. Student centered instruction places students in the center of learning [7]. Student centered learning environments are designed to support individual efforts in authentic activities [10]. According to [10] students centered learning environments reflect various assumptions;

- Centrality of the learner in deriving meaning

- Students' participation in authentic tasks and sociocultural procedure 
- Importance of prior and everyday experience in meaning construction

- Access to multiple perspectives, resources and representations.

Starting from the emergence of the constructivist view of learning, new frameworks for designing learning environments have emerged [10]. Several approaches fitting the student-centered learning have been developed throughout the years. [7] lists these approaches as

- Active learning

- Collaborative learning

- Inquiry-based learning

- Cooperative learning

- Problem-based learning

- $\quad$ Peer led team learning

- $\quad$ Team based learning

- Peer instruction

- Inquiry guided learning

- Just-in-time learning

The characteristics of teachers who play an important role in the educational process should be in this direction. Teachers who adopt student-centered education may contribute to the structuring by acting in line with the principles of the constructivist approach. Such teachers should not only provide information, but also should make students aware of the restructuring of information, should make students more active in the learning environment, should support their initiatives, should shape the course according to student reactions, should organize appropriate materials, should provide collaborative activities, should prepare debate and problem solving environment [22]. The information transferred by the teachers to the students is influential in their knowledge structuring in line with their level of cognitive development. The development of students' problem-solving skills, analytical thinking and inquiry skills, mental rather than memorizing, and effective use of information in everyday life problems vary depending on the quality of the teaching environment [23]. Knowing which methods to teach teachers with which methods and techniques can lead to positive results in the learning process and inadequacy in methods and techniques can also cause negative results. Therefore, it seems that the methods and techniques that are tools for learning are directly related to the ability to use it [14]. Functionality in diversity, methods and techniques in the student-centered learning environment is an important step in the discovery of the skills and abilities of the learners.

Student-centered teaching methods have positive aspects as well as negative aspects. For example, in the method of discussion, student-centered teaching methods have positive aspects such as the development of communication skills of the students, but also negative aspects such as taking too much time and causing noise in the class. Being another method, cooperative learning method, has negative aspects such as individual helplessness, fear of showing less skill, wasting time with positive aspects such as being respectful to others' ideas, empathizing and taking responsibility [17]. Because of the reasons mentioned above, while some teachers are positive about using student-centered teaching methods and techniques, some of them are also abstaining. There are different studies in which the reflection of the use of student-centered teaching methods and strategies is examined.

In lessons with practice such as science, students emphasize that the student-centered method is more effective than the teacher-centered method [5]. Implemented properly, student centered instruction can increase motivation, retention of knowledge, and attitudes [7]. The student-centered approach indicated that student success was positively affected in the environments where active learning was used [2]. On the other hand, it has been determined that the perceptions about the student centered approach of the teachers working in elementary schools are positive [13], because teachers are using the student centered method at middle level and the main reason is classroom attendance. However, it is understood that student-centered approaches are used on the middle level in high schools [1]. There are also student-centered practices developed for crowded classes [18].

It is important to compare the attitude of teachers towards student-centered teaching methods and strategies today to investigate whether the attitude of teachers change based on the gender, subject, seniority year, and school type. The results of this study can be used to identify teacher groups who need additional support to change their attitude towards student-centered teaching methods and strategies in order to increase the use of teaching methods and strategies in learning environments. The goal of this study is to determine the attitude of teachers working in secondary schools to use student centered teaching methods and techniques and compare it based on the gender, subject, seniority year, and school type variables. For this purpose following research question and sub-questions were developed.

\subsection{The Research Question and Sub-Questions}

How does the attitude of teachers working in secondary schools to use student-centered teaching methods and techniques change based on the gender, subject, seniority year, and school type? Based on this research question following sub-questions were investigated;

1. How does the attitude of teachers working in secondary schools change based on the gender?

2. How does the attitude of teachers working in secondary schools change based on the school type?

3. How does the attitude of teachers working in secondary schools change based on the seniority?

4. How does the attitude of teachers working in secondary schools change based on the course type? 


\section{Methods}

This study was carried out using the survey method because survey method is suitable to investigate the current and past conditions [11].

\subsection{Population and Sample}

The population of the research is 409 subject teachers who work in the secondary schools in one city located in the Blacksea region in the 2017-2018 academic year. Using random sampling [11] ten secondary schools were identified and teachers of these schools were asked to participate the study. 135 teachers voluntarily participated in the study. The characteristics of the sample teachers are given in Table 1.

Table 1. Demographics of Teachers

\begin{tabular}{lll}
\hline Variables & N & $\%$ \\
\hline Gender & 70 & 51.86 \\
\hline Female & 65 & 48.14 \\
\hline Male & & \\
\hline Course Type & 38 & 28.15 \\
\hline Numeric Courses & 58 & 42.96 \\
\hline Verbal Courses & 39 & 28.9 \\
\hline Skill Courses & & \\
\hline School Type & 43 & 31.85 \\
\hline Private & 92 & 68.15 \\
\hline State & & \\
\hline Work Experience & 19 & 14.07 \\
\hline $1-5$ & 23 & 17.04 \\
\hline $6-10$ & 47 & 34.82 \\
\hline $11-15$ & 46 & 34.07 \\
\hline 16 and above & 135 & 100 \\
\hline Total & & \\
\hline
\end{tabular}

According to Table 1, it is seen that the group forming the sample is distributed homogeneously in terms of gender, lectures and seniority years. The number of teachers working in private schools (43) is less than the number of teachers working in public schools (92).

\subsection{Data Collection and Analysis}

In this study, the scale developed by [12] was used to determine the attitudes of teachers towards using student-centered teaching methods and techniques. The scale was prepared in the form of a five-point Likert type with positive and negative items. (1) Strongly Disagree, (2) Agree, (3) Undecided, (4) Agree, and (5) Strongly Agree. The explanatory and the confirmatory factor analysis was performed for the construct validity of the scale. As a result of exploratory and confirmatory factor analysis, the 27 -item with 4 factor scale was obtained. To examine the reliability of the scale, item-total score correlations, Cronbach Alpha coefficients and two half-test correlation (Spearman Brown) coefficients were calculated. For the whole scale, the Cronbach alpha coefficient was 0.93 and 0.94 for valuation, 0.89 for resistance, 0.90 for positive effect, and 0.84 for cost perception.

The data obtained in the study were analyzed using SPSS 20.0 (Statistical Package for Social Sciences) statistical program. Analysis were made based on whether the data showed normal distribution or not. To determine whether there is a meaningful difference in gender and school type variables, unrelated sample t-test was used for normal distribution data and Mann Whitney U test was used for non-normal distribution data. The Mann Whitney $\mathrm{U}$ test can be used as an alternative to the unrelated t-test when the normality assumption of the scores is not met [4]. One way analysis of variance was used to determine whether there was a meaningful difference in the variables of the course and seniority years. In cases where normality is not provided, the Kruskall Wallis-H test, which is a non-parametric test, is used instead of analysis of variance. In the case of a significant difference in the result of the Kruskall Wallis-H test, Mann Whitney U test was applied over the binary combinations of the groups and the source of the difference was examined.

\section{Findings}

The attitudes of teachers towards using student-centered teaching methods and techniques are presented in the following tables for each sub-research questions.

\subsection{How Does the Attitude of Teachers Working in Secondary Schools Change Based on the Gender?}

The results of the question which investigate how the attitude of teachers working in secondary schools changes based on the gender are presented at Table 2 and Table 3.

According to the results in Table 2, when teachers' attitudes towards using student centered teaching methods and techniques were examined according to gender variables, it was found that there was no meaningful difference in the overall scale, even though the average mean rank of female teachers were high in sub-factors ( $\mathrm{p}>$ $0.05)$.

According to the results in Table 3, when teachers' attitudes towards using student-centered teaching methods and techniques were examined by gender variable, there was no significant difference in resistance and cost perceived sub-factors $(\mathrm{p}>0.05)$. 
Table 2. Comparison of the teachers' attitude, valuing, positive influence based on the gender

\begin{tabular}{|c|c|c|c|c|c|c|}
\hline Sub factors & Gender & $\mathrm{N}$ & Mean rank & Total rank & MWU & $\mathrm{p}$ \\
\hline \multirow{2}{*}{ Valuing } & Female & 70 & 71.84 & 5028.5 & \multirow{2}{*}{2006.5} & \multirow{2}{*}{0.234} \\
\hline & Male & 65 & 63.87 & 4151.5 & & \\
\hline \multirow{2}{*}{ Positive influence } & Female & 70 & 73.30 & 5131.0 & \multirow{2}{*}{1904.0} & \multirow{2}{*}{0.095} \\
\hline & Male & 65 & 62.29 & 4049.0 & & \\
\hline \multirow{2}{*}{$\begin{array}{l}\text { In general } \\
\text { (attitude) }\end{array}$} & Female & 70 & 73.55 & 5148.5 & \multirow{2}{*}{1886.5} & \multirow{2}{*}{0.087} \\
\hline & Male & 65 & 63.02 & 4031.5 & & \\
\hline
\end{tabular}

Table 3. Comparison of the teachers' cost perception and resistance based on the gender

\begin{tabular}{lllcccc}
\hline Sub factors & Gender & $\mathrm{N}$ & $\mathrm{X}$ & $\mathrm{S}$ & $\mathrm{T}$ & $\mathrm{p}$ \\
\hline \multirow{2}{*}{ Showing resistance } & Female & 70 & 3.48 & 0.35 & 1.88 & 0.63 \\
& Male & 65 & 3.36 & 0.42 & & 0.19 \\
\hline \multirow{2}{*}{ Cost perception } & Female & 70 & 3.29 & 0.79 & 1.32 & 0.78 \\
& Male & 65 & 3.11 & 0.19 & \\
\hline
\end{tabular}

Table 4. Comparison of the teachers' attitude, valuing, positive influence based on the school types

\begin{tabular}{lllcccc}
\hline Sub-factors & School Types & $\mathrm{N}$ & Mean rank & Rank total & MWU & $\mathrm{p}$ \\
\hline \multirow{2}{*}{ Valuing } & Private & 43 & 66.45 & 2857.5 & 1911.5 & 0.752 \\
& State & 92 & 68.72 & 6322.0 & & 0.592 \\
\hline \multirow{2}{*}{ Positive effects } & Private & 43 & 65.42 & 2813.0 & 1867.0 & \\
\hline In general & State & 92 & 69.21 & 6367.0 & & 0.660 \\
(attitude) & Private & 43 & 65.84 & 2831.0 & 1885.0 & \\
\hline
\end{tabular}

Table 5. Comparison of the teachers' showing resistance and perceived cost based on the school types

\begin{tabular}{ccccccc}
\hline Sub-factors & School Type & $\mathrm{N}$ & $\mathrm{X}$ & $\mathrm{S}$ & $\mathrm{t}$ & $\mathrm{p}$ \\
\hline \multirow{2}{*}{ Showing resistance } & Private & 43 & 3.45 & 0.39 & 0.515 & 0.61 \\
& State & 92 & 3.41 & 0.39 & & 0.45 \\
& Private & 43 & 3.13 & 0.85 & 0.76 & 0.45 \\
\hline \multirow{2}{*}{ Perceived cost } & State & 92 & 3.24 & 0.76 & & \\
& & &
\end{tabular}

\subsection{How Does the Attitude of Teachers Working in Secondary Schools Change Based on the School Type?}

The results of the question which investigate how the attitude of teachers working in secondary schools changes based on the school type are presented at Table 4 and Table 5.

According to the results in Table 4, when teachers' attitude towards using student centered teaching methods and techniques were examined according to the school type variable, there was no significant difference between the scale and positive effect subscales ( $p>0.05$ ). Therefore, it is understood that there is no distinction in this study between the teachers working in the private school or public school in using student centered methods and techniques.

According to the results in Table 5, when teachers' attitude towards using student-centered teaching methods and techniques were examined according to school type variable, there was no significant difference in showing resistance and cost perceived sub-dimension $(\mathrm{p}>0.05)$.

\subsection{How Does the Attitude of Teachers Working in Secondary Schools Change Based on the Seniority?}

The results of the question which investigate how the attitude of teachers working in secondary schools changes based on the seniority are presented at Table 6 and Table 7.

According to Table 6, when teachers' attitude towards using student centered teaching methods and techniques were examined according to seniority variable, there was no significant difference between the scale and positive effect subscales ( $p>0.05$ ). Positive effects according to findings, the average of the teachers working for 11-15 years in the sub-dimension is higher than the others. In the valuing sub-dimension, the average number of teachers working in 16 and more is higher. However, there is still no significant difference.

According to the results in Table 7, when teachers' attitude towards using student centered teaching methods and techniques were examined according to the variable of seniority years, there was no significant difference in resistance and cost perceptions subscale $(p>0.05)$. The rank order for seniority years shows similar values. 
Table 6. Comparison of the teachers' attitude, valuing, positive influence based on the seniority

\begin{tabular}{|c|c|c|c|c|c|c|}
\hline Sub-factor & Work Experience & $\mathrm{N}$ & Mean Rank & $\mathrm{sd}$ & $\mathrm{X}^{2}$ & $\mathrm{p}$ \\
\hline \multirow{4}{*}{ Valuing } & $1-5$ & 19 & 69.1 & \multirow{4}{*}{3} & \multirow{4}{*}{1.09} & \multirow{4}{*}{0.368} \\
\hline & $6-10$ & 23 & 65.5 & & & \\
\hline & $11-15$ & 47 & 64.5 & & & \\
\hline & 16 and plus & 46 & 72.4 & & & \\
\hline \multirow{4}{*}{ Positive effects } & $1-5$ & 19 & 77.3 & \multirow{4}{*}{3} & \multirow{4}{*}{3.12} & \multirow{4}{*}{0.779} \\
\hline & $6-10$ & 23 & 62.1 & & & \\
\hline & $11-15$ & 47 & 62.8 & & & \\
\hline & 16 and plus & 46 & 72.5 & & & \\
\hline \multirow{4}{*}{$\begin{array}{l}\text { In general } \\
\text { (attitude) }\end{array}$} & $1-5$ & 19 & 67.5 & \multirow{4}{*}{3} & \multirow{4}{*}{3.18} & \multirow{4}{*}{0.365} \\
\hline & $6-10$ & 23 & 69.2 & & & \\
\hline & $11-15$ & 47 & 60.7 & & & \\
\hline & 16 and plus & 46 & 75.1 & & & \\
\hline
\end{tabular}

Table 7. Comparison of the teachers' showing resistance and perceived cost based on the seniority

\begin{tabular}{lllllll}
\hline Sub-factors & Seniority & $\mathrm{N}$ & $\mathrm{X}$ & $\mathrm{SS}$ & $\mathrm{F}$ & $\mathrm{p}$ \\
\hline \multirow{5}{*}{ Showing resistance } & $1-5$ & 19 & 3.46 & 0.31 & & \\
& $6-10$ & 23 & 3.52 & 0.43 & 1.18 & 0.320 \\
& $11-15$ & 47 & 3.34 & 0.46 & & \\
& 16 and more & 46 & 3.42 & 0.23 & & \\
Perceived cost & $1-5$ & 19 & 3.05 & 1.05 & & 0.303 \\
& $6-10$ & 23 & 3.22 & 0.73 & & \\
& $11-15$ & 47 & 3.10 & 0.81 & & \\
\hline
\end{tabular}

Table 8. Comparison of the teachers' attitude, valuing, positive influence based on the course type

\begin{tabular}{|c|c|c|c|c|c|c|c|}
\hline Sub factors & Courses & $\mathrm{N}$ & Mean Rank & $\mathrm{sd}$ & $\mathrm{X}^{2}$ & $\mathrm{p}$ & Significant Difference \\
\hline \multirow{3}{*}{ Valuing } & Numeric Courses & 38 & 63.4 & \multirow{3}{*}{2} & \multirow{3}{*}{6.87} & \multirow{3}{*}{$0.032 *$} & \multirow{3}{*}{ Skill>Verbal, Numeric } \\
\hline & Verbal Courses & 58 & 61.8 & & & & \\
\hline & Skill Courses & 39 & 81.7 & & & & \\
\hline \multirow{3}{*}{$\begin{array}{l}\text { Positive } \\
\text { effects }\end{array}$} & Numeric Courses & 38 & 66.4 & \multirow{3}{*}{2} & \multirow{3}{*}{2.96} & \multirow{3}{*}{0.228} & \\
\hline & Verbal Courses & 58 & 63.3 & & & & \\
\hline & Skill Courses & 39 & 76.67 & & & & \\
\hline \multirow{3}{*}{$\begin{array}{l}\text { In general } \\
\text { (attitude) }\end{array}$} & Numeric Courses & 38 & 63.5 & \multirow{3}{*}{2} & \multirow{3}{*}{2.16} & \multirow{3}{*}{0.034} & \\
\hline & Verbal Courses & 58 & 63.8 & & & & \\
\hline & Skill Courses & 39 & 75.6 & & & & \\
\hline
\end{tabular}

$\mathrm{p}<0.05$

Table 9. Comparison of the teachers' cost perception and resistance based on the course types

\begin{tabular}{lllllll}
\hline Sub-factors & Courses & N & X & SS & F & p \\
\hline \multirow{3}{*}{ Showing resistance } & Numeric Courses & 38 & 3.44 & 0.30 & & 0.927 \\
& Verbal Courses & 58 & 3.42 & 0.44 & 0.760 & 0.38 \\
& Skill Courses & 39 & 3.41 & 0.77 & & \multirow{2}{*}{0.824} \\
\multirow{3}{*}{ Perceived cost } & Numeric Courses & 38 & 3.15 & 0.79 & 0.193 & \\
& Verbal Courses & 58 & 3.25 & 0.81 & & \\
& Skill Courses & 39 & 3.18 & &
\end{tabular}

\subsection{How Does the Attitude of Teachers Working in Secondary Schools Change Based on the Course Type?}

The results of the question which investigate how the attitude of teachers working in secondary schools changes based on the course type are presented at Table 8 and Table 9.

According to the data in Table 8, when teachers' attitude towards using student centered teaching methods and methods were examined according to the course types, no significant difference was found between the scale and positive effect sub-dimensions ( $p>0.05$ ). However, there was a significant difference between the course types in the valuing sub-dimension $(\mathrm{p}<0.05)$. This difference shows that in the skills lessons, the teachers use more student-centered teaching methods and techniques than the verbal and numerical lessons.

According to the data in Table 9, when teachers' attitude towards using student-centered teaching methods and techniques were examined according to course types, there was no significant difference in resistance and cost 
perceived subscale $(p>0.05)$. It is understood that the type of course does not make a difference in these sub-dimensions.

\section{Discussion and Conclusions}

The importance given to student-centered teaching methods and techniques is increasing as a reflection of the constructivist approach. This study was conducted with the aim of determining the attitude of teachers working in secondary schools to use student centered teaching methods and techniques and compare it based on the gender, subject, seniority year, and school type variables. The data collection scale used consists of four sub factors. All variables were evaluated separately for each sub-factor. According to gender variable, no significant difference was found in all sub-factors and scale-wide. That is, the use of student-centered teaching methods and techniques did not differ whether teachers were male or female. Despite the fact that the average attitudes of female teachers were higher than that of men, no difference was observed. In [13]'s study of primary school teachers' perceptions towards student centered teaching, it was seen that there was no difference according to the gender.

There was no significant difference in all sub-dimensions according to the school type sub-variable and the scale general. The use of student-centered teaching methods and techniques did not differ according to whether the schools were private schools or state schools. In a study by [15], it was found that teachers working in private schools had more seminars in school than teachers in public schools. It also revealed that teachers can apply more student-centered teaching methods and techniques due to reasons such as low number of students in private schools, more sporting activities, high number of foreign language lesson hours, excessive school budgets, and strong physical equipment [21]. [21]'s findings contradict to the findings of this study. It is determined in this study that teachers in private schools do not have a high attitude relative to those in public schools. Today, the number of projects made in the field of education is increasing in public schools as well as in private schools. Technologically oriented classroom environments are created and rich material resources can be provided to schools [6]. Therefore, attitudes of teachers in public schools can change positively and can be the same as private school standards.

No significant differences were found in the comparison of findings on the scale according to seniority. The use of the student centered teaching method and technique did not make any difference as long as the teachers were in office. When we look at the average of the scale, it is seen that the attitudes of the teachers who worked for 16 years and over are higher than the teachers who worked for 1-5, 6-10 and 11-15 years. A teacher using student-centered teaching methods and techniques should have the necessary knowledge about the emotional, cognitive and developmental characteristics of the students and should act in accordance with the interests and abilities of the students. It can be said that the teachers who worked at 16 and over were rooted in the experience of the reasons for the high attitude averages [3].

There was no significant difference in the attitudes towards the branch variable, cost beliefs, positive effects sub-dimensions and the attitudes of teachers throughout the scale, but when the averages were examined, the attitudes average of the teachers of skill classes was higher in all variables. Based on this finding, it is seen that the attitudes of the teachers who have entered into the skill classes to use student-centered teaching methods and techniques are more positive. In the valuation subscale, the difference in points in the skill classes reached a level that would make a significant difference. According to the verbal and numerical subjects, the teachers' attitude towards the use of student-centered teaching methods and techniques in skills classes was higher. The methods and techniques used by teachers in the courses where physical education, music, painting, technology, design, information technology, etc. are actively involved should also be student-centered because learners in student centered learning act as a co-creators in the learning [7]. It is thought that effective participation of students in verbal and numerical courses takes time. It may therefore be assumed that teachers do not prefer to use student-centered teaching methods and techniques. In a study conducted by [8], it was stated that the students could not have enough time because of the crowded class. Therefore it was difficult to carry out their studies. Establishment of educational environment where there are classes devoted to branches where students can work comfortably can affect the use of student-centered teaching methods and techniques positively in all subjects.

\section{Suggestions for Further Research}

It should be remembered that the teachers' educational background information about the use of student-centered teaching methods and techniques were not investigated and used during the analysis of the findings. Collecting the background information of teachers and making interpretation based the background information of the teachers may produce different results.

Future work should investigate why the attitudes of teachers offering skill lessons towards using student-centered teaching methods and techniques are high as compared to the attitudes of teachers offering verbal and numerical lessons. In addition, it is understood that senior teachers with high seniority prefer to use student-centered methods and techniques more than other teachers. Future studies should examine why teachers offering skill lessons and teachers with high seniority have 
a high level of attitudes towards student-centered teaching methods and techniques using interviews, observations and document analysis data.

\section{REFERENCES}

[1] Aliusta, G. O., Ozer, B., \& Kan, A. (2015). The implementation of student-centred instructional strategies in schools in North Cyprus. Eğitim Ve Bilim-Education And Science, 40(181), 77-91.

[2] Aydede, M. N., \& Matyar, F. (2009). The Effect of Active Learning Approach in Science Teaching on Cognitive Level of Student Achievement. Journal of Turkish Science Education, 6(1), 115-127.

[3] Bulut, İ. (2008). Teacher Views on Student-Centred Practices in the New Primary Education Curriculum. Educational Administration: Theory and Practice, 14(4), 521-546.

[4] Büyüköztürk, Ş. (2007). Manual of data analysis for social sciences. Ankara: Pegem Academy Publishing.

[5] Deniz, İ. (2005). Impact of student-centred science education on student achievement. Master Thesis, Pamukkale University, Denizli, Turkey.

[6] Ergün, M., \& Özsüer, S. (2004). Participation (or not) in class in primary education. In Proceedings of the International Symposium on Democracy Education 20-21 May 2004 (pp. 169-178), Çanakkale, Turkey.

[7] Froyd, J., \& Simpson, N. (2008, August). Student-centered learning addressing faculty questions about student centered learning. In Course, Curriculum, Labor, and Improvement Conference, Washington DC, 30 (11).

[8] Güven, S. (2008). The Classrom Teachers' Views Concerning The Application Of The New Primary School Programmes. Journal of National Education, 177(224-236).

[9] Hannafin, M. J., Hill, J. R., \& Land, S. M. (1997). Student-centered learning and interactive multimedia: Status, issues, and implication. Contemporary Education, 68(2), 94.

[10] Jonassen, D., \& Land, S. (Eds.). (2012). Theoretical foundations of learning environments. Routledge.

[11] Karasar, N. (2003). Scientific research method (13th edition). Ankara: Nobel Publishing.

[12] Koç, C. (2014). Öğrenci merkezli öğretim yöntem ve tekniklerini kullanmaya yönelik tutum ölçeği: geçerlik ve güvenirlik çalışması. Elektronik Sosyal Bilimler Dergisi, 49(49).

[13] Maden, S., Durukan, E., \& Akbaș, E. (2011). [Primary school teachers' perceptions of student centred teaching. Mustafa Kemal University Journal of Social Sciences Institute.

[14] Özden, Y. (1997). Learning and teaching. Ankara: Pegem Academy Publishing.

[15] Özgan, H., Yiğit, C., Aydın, Z., \& Küllük, M. C. (2010).
Analysis and Comparison of Primary School Teachers' Perceptions About Classroom Management. Gaziantep University Journal of Social Sciences, 10(1), 615-635.

[16] PISA-2006. (2007). PISA 2006 international student achievement assessment program national preliminary report. Retrieved from http://pisa.meb.gov.tr/wp-content/up loads/2013/07/PISA2006-Ulusal-Nihai-Rapor.pdf

[17] Taşpınar, M. (2012). Teaching principles and methods (5th edition]. Ankara: Pegem Academy Publishing.

[18] Topbaş, E., \& Toy, B. Y. (2007). An evaluation of the application of student centred education in crowded classrooms: instructional planning and evaluation course example. Journal of Turkish Educational Sciences, 5(3).

[19] Woolfolk, A. 2005. Educational Psychology, 9th ed., Boston, MA: Allyn \& Bacon.

[20] Yıldırım, A., \& Şimşek, H. (1999). Qualitative research methods. Ankara: Seçkin Publishing.

[21] Eyüpoğlu, R. (2002). Genel Değerlendirme. Özel okullar ve eğitimde kalite (Ed: İ. Erdoğan) İstanbul: Özel Okullar Derneği Yayını.

[22] Kutluca, T. (2013). Yapılandırmacı öğrenme öğretme yaklaşımı. (Ed. G. Ekici ve M. Güven). Öğrenme öğretme yaklaşımları ve uygulama örnekleri (1.Baskı). Ankara: Pegem Yayınevi.

[23] Erdem, Gürlen, E. (2011). Probleme dayalı öğrenme. (Ed. Ö.Demirel). (81-91). Eğitimde yeni yönelimler (5.Bask1). Pegem Akademi. 